\title{
難治性喘息とは何か： 注意点と治療実践
}

要 旨

難治性喘息とは, 高容量ステロイド薬, 経ロステロイド薬, 抗IgE （immunoglobulin E) 抗体の投与, その他の喘息治療薬をコントロールに 福冨友馬 要する喘息, または, これらの治療を行ってもコントロール不良な喘息で ある. 難治性喘息の診断において最も重要なことは, 喘息様症状を示す他 疾患を適切に鑑別することである. 喘息の難治化因子としては, 肥満, ア スピリン感受性, 非アトピー型, 真菌感作等が重要である,

〔日内会誌 $107 ： 2097 〜 2103 ， 2018$ ]

Key words difficult-to-treat asthma, severe asthma, obesity, aspirin-exacerbated respiratory diseases (AERD)

\section{はじめに}

2000 年以降の吸入ステロイド薬を中心とす る有効な喘息治療薬の普及により, 多くの喘息 患者のコントロールが改善されてきた。しか し，このように，抗喘息薬が十分に普及した現 代に拈てても，十分な投薬にもかかわらず，症 状がコントロールできない喘息症例, すなわ ち, 難治性喘息症例も少なからず経験する。こ の患者群は, 発作による救急室受診や入院の頻 度の高さのみならず，医療費に占めるインパク トの大きさからみても, 社会的に注目すべき喘 息患者集団である ${ }^{1)}$ 。本稿では，難治性喘息の 概念, 鑑別ならびに対処方法について概説する。

\section{1. 難治性喘息の概念と鑑別診断}

本邦の「喘息予防・管理ガイドライン $2018 」$ (日本アレルギー学会, 2018年) 2)では, 難治性 喘息を「コントロールに高容量吸入ステロイド 薬および長時間作用性 $\beta_{2}$ 刺激薬，加えてロイコ トリエン受容体拮抗薬，テオフィリン除放製 剂, 長時間作用性抗コリン薬, 経ロステロイド 薬, IgEやIL-Sを標的とした生物学的製剤の投与 を要する喘息，またはこれらの治療でもコント ロール不能な喘息」と定義している．難治性喘 息は，一般的に重症喘息とも呼ばれる.

難治性喘息の診断において最も重要なこと は，喘息様症状を示す他疾患を適切に鑑別する ことである。すなわち，喘息であると思われて いた患者の気道症状が，真に喘息によるもので あるのかどうかということを再評価する必要が 
$\checkmark$ 喘息の診断は正しいか?

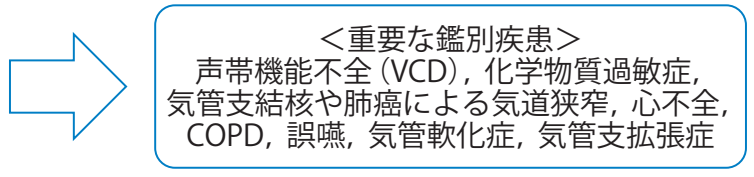

$\checkmark$ 吸入手技は正しいか? 服薬アドヒアランスは良好か ?

$\checkmark$ 喘息特殊病態は合併していないか？

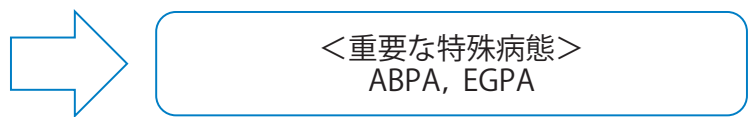

図 1 難治性喘息・重症喘息と診断する前に考慮すべきこと

COPD : chronic obstructive pulmonary disease,

ABPA：アレルギ一性気管支肺アスペルギルス症，

EGPA：好酸球性多発血管炎性肉芽腫症

ある、鑑別すべき重要な疾患を図 1 に挙げた。

鑑別疾患で挙げられたこれらの疾患の気道症状 に対しては，通常，吸入ステロイド薬（吸入手 技が適切であることが前提）や全身性ステロイ ド薬の効果は認められない。この点が, 症状が 改善しない喘息様症状を来たす患者の診療にお いて，喘息以外の疾患を疑うポイントになるこ とが少なくない。

ここで注意しなければならない点として，時 に誤解されていることがあるが，難治性喘息に 対しては，抗喘息薬が “十分な効果を示さない” のであり, “全く効果を示さない”わけではない ということである，具体的には，難治性喘息患 者であっても，十分量の全身性ステロイド薬を 1 週間以上投与すれば，少なくとも一時的には， 気道症状がほぼ消失，もしくは大幅に改善する （極めて稀ながら，最重症の喘息例では例外あ り). 同時に, 全身性ステロイド薬投与を終了す ると, 比較的短期間で再燃することが多いのが 難治性喘息の特徴である。一方, 図 1 に示した 鑑別疾患に対しては, 通常, 全身性ステロイド 薬投与はほぼ効果がない。全身性ステロイド薬 投与が効果を示さない場合は, 通常, 難治性喘 息ではなく，図10ような鑑別疾患を疑って精
査を行うべきである，全身性ステロイド薬を投 与すると，気道症状の改善の有無にかかわら ず，一時的に“元気になる”ため，患者は，そ のことを指してステロイド投与が効果があった と訴えることがあるが，ステロイドが真に気道 症状の改善に寄与しているかどうかについて は, 慎重に見極める必要もある.また, 難治性 喘息と診断する際には，喘息病態が重症である ことを示す何らかの客観的なエビデンスを掴み にいく努力は必要である. 肺機能検査やFeNO (fractional exhaled nitric oxide) 測定, 気道過敏 性検査, 胸部CT (computed tomography) 等の 臨床検査やピークフローの変動等, 症状のみな らず，客観的所見によっても，喘息病態が重症 であることを示す必要がある。実地臨床では, 喘息であるという客観的エビデンスが全くない にもかかわらず，喘息様の気道症状がステロイ ド投与にて改善しないという理由だけで，難治 性喘息と誤診されている事例を経験することも 少なくない.

また，診療ガイドライン等には記載されてい ないが, 近年, 頻度が高くなっている喘息様症 状を来たす疾患の鑑別診断として, 化学物質過 敏症が挙げられる（図1)。本疾患は多彩な症状 
を呈するが，咳や呼吸困難を主訴に呼吸器外来 を受診することも少なくない。典型的な症状 は, 香水や柔軟剤のにおい, たばこの煙, 新築 の建材のにおい等の吸入性化学物質曝露後に, 特に咳嗽や呼吸困難感等の気道症状の増悪を認 めるものであり，喘鳴を来たすことは比較的稀 である（稀ながら, 化学物質過敏症の症状とし て喘鳴を来たすこともある). 本疾患は疾患概念 自体が未だ医学的に確立されていないが，この ような患者群が実地臨床では確実に存在する. この疾患に対しても, 全身性ステロイド薬投与 の効果は乏しいため, 本来は喘息との鑑別は可 能であるが, 近年, 難治性喘息と䛊診される化 学物質過敏症患者が増加している印象がある. 本疾患は多種過敏症状の 1 つして, 薬剤過敏 を合併しやすく, 非ステロイド性抗炎症薬 (non-steroidal anti-inflammatory drugs : NSAIDs）内服時にも何らかの副反応を来たしや すいため, アスピリン喘息 (aspirin-exacerbated respiratory diseases：AERD）と誤診されること も少なくない.

また，図 1 に示した鑑別疾患が軽症の喘息に 合併することもある．喘息患者が訴える気道症 状が必ずしも全て喘息によるものとは限らな い.すなわち，客観的な所見で診断された喘息 患者に対しても, 通常の治療が奏効しない場合 には，このような鑑別疾患が “合併”していな いか, 留意する必要がある.

\section{2. 難治性喘息の頻度}

病院に受診していないような軽症者も含む一 般住民における喘息患者集団においては，半数 以上が軽症喘息であり, 難治性喘息患者の占め る割合はあまり高くはない. しかしながら, 地 域の基幹病院に通院している成人喘息患者群に 関して言えば，難治性喘息は決して稀ではな い.やや古いデータであるが，我々は 2006 年 に国立病院機構のネットワーク研究で本邦の成
人喘息患者の大規模な実態調査を行った ${ }^{3)}$. ス テップ4の治療をしても, 十分なコントロール が得られていない症例を難治性喘息と定義する と，それは全体の約 $15 \%$ を占めており，決して 稀とはいえない結果であった。性別・年齢階級 別にみると, 難治性喘息は男女ともに 45～64歳 群でそれぞれ $18 \%, 17 \%$ で,他の年齢階級に比 べ頻度が高く, 喘息難治化は必ずしも高齢者に 限った現象ではなかった。

\section{3. 喘息難治化因子}

これまでに欧州，米国ならびに本邦から報告 されている喘息難治化因子に関わる大規模な臨 床研究の結果を要約し, 表 1 に示した. 肥満, 副鼻腔炎, 非アトピー, アスピリン感受性等の 因子が難治化因子として挙げられており, 国際 的に比較してみても, これらの難治化因子の普 遍性は比較的高いことが伺い知れる。これらの 検討は, 重症/難治性喘息患者群とそうでない喘 息患者群の背景因子を単純に比較したものであ る. 従って, これらは遭遇する頻度が比較的高 い難治化因子であると言ってよいが, 頻度が高 くなくても, 臨床的に重要な難治化因子は他に

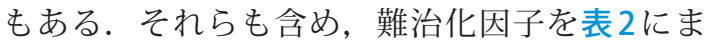
とめた。近年は特に真菌感作と喘息難治化の関 係への関心が高まっている.アスペルギルスに 感作された喘息患者は，アレルギー性気管支肺 アスペルギルス症 (allergic bronchopulmonary aspergillosis：ABPA）の診断基準を満たさなく ても，低肺機能を示し，喘息が重症であること が示されている。

\section{4. 喘息難治化因子への対応}

難治性喘息への対処方法としては, 薬物療法

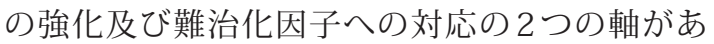
る. 薬物療法の強化としては, 吸入療法の強化 のみならず，ステロイド全身投与や分子標的療 
表 1 難治性喘息とコントロール良好な喘息との背景因子の特徵 -ENFUMOSA Study, SARP Study, 相模原病院症例の比較—

\begin{tabular}{|c|c|c|c|}
\hline & $\begin{array}{c}\text { 欧州 } \\
\text { ENFUMOSA }\end{array}$ & $\begin{array}{l}\text { 米国 } \\
\text { SARP }\end{array}$ & $\begin{array}{c}\text { 日本 } \\
\text { 相模原病院症例 }\end{array}$ \\
\hline 年齢 & 違いなし & 高齢である & 高齢である \\
\hline 罹病期間 & 報告なし & 長期である & 長期である \\
\hline 性別 & 女性（4：1） & 違いなし & 違いなし \\
\hline BMI & 女性のBMI高值 & 違いなし & 女性の BMI $\geq 30$ \\
\hline アトピーvs 非アトピー & 非アトピー & 非アトピー & 非アトピー \\
\hline アスピリン感受性 & 感受性あり & 感受性あり & 感受性あり \\
\hline 副鼻腔炎 & 女性の副鼻腔炎 & 男女共に副鼻腔炎 & 違いなし \\
\hline GERD & 報告なし & 増加 & 報告なし \\
\hline
\end{tabular}

ENFUMOSA : Eur Respir J 22 : 470-477， 2003 参照

SARP : J Allergy Clin Immunol 119：405-413，2007 参照

相模原病院症例：Clin Exp Allergy $42 ： 738-746 ， 2012$ 参照

\section{表 2 気管支喘息の難治化因子}

$\checkmark$ AERD の合併
$\checkmark$ 肥満
$\checkmark$ 副鼻腔炎
$\checkmark$ 非アトピー型
$\checkmark$ 真菌感作
$\checkmark$ 職業性因子
$\checkmark$ 喫煙
$\checkmark$ COPD，肺結核後遺症の合併
$\checkmark$ 持続性アレルゲン曝露 (ペット，職業性アレルゲン)
$\checkmark$ 女性因子
AERD : aspirin-exacerbated respiratory diseases

法薬を考慮することになる。これらの薬物療法 では，当該患者の喘息臨床亜型を評価し，各患 者に最も適した薬剤を選択していくことになる が, 本稿では, このプロセスに関しては割愛し, 難治化因子への対応に関して，以下に詳述す る。難治性喘息患者に対しては，これらの難治 化因子の一つひとつの保有があるかどうかを評 価し，当該患者の病態に最も関与していると考 えられる因子から順にフォーカス当てて介入す ることになる．

\section{1）肥満合併喘息への対応}

近年の研究によって, 肥満が喘息の難治化・ 重症化に関与していることが明らかになってき た.また，近年，盛んに報告されている喘息ク ラスター解析においても一貫して, 肥満が強く 関与する喘息亜型が存在することが示されてい る ${ }^{4)}$.この亜型は, 成人発症, 非アトピー型, 女性優位で, 肥満者が多く, 非好酸球性炎症, 低い喘息コントロール, 強い喘息症状で特徵付 けられる，比較的特異なフェノタイプであると されている，この知見は，肥満が強く関与した 比較的重症の喘息群，すなわち「肥満関連喘息」 とでも言うべき喘息亜型が存在することを示し ている，我々が行った相模原病院の外来喘息患 者を対象とした研究においても, BMI（body mass index） $30 \mathrm{~kg} / \mathrm{m}^{2}$ 以上の肥満が喘息の難治 化因子として見出されているが, 層化解析を行 うと，特に女性の非アトピー型喘息群におい て，肥満が重要な難治化因子であることも明ら かになっている5).

肥満が喘息の発症や重症化に関与するメカニ ズムとして，いくつかの説明がなされている. まずは, 肥満による肺機能への直接的な影響が 存在する。 また, 肥満による免疫学的変化も関 
与している。一般に，内臓の肥大化した脂肪組 織からは, アディポカインと総称される生理活 性物質(レプチン, TNF(tumor necrosis factor)- $\alpha$, IL（interleukin)-6等）が分泌され，これが慢性 持続性炎症を引き起こし，インスリン抵抗性, 2 型糖尿病, 非アルコール性脂肪肝, 動脈硬化 に関係するとされているが，この病態が喘息の 発症や難治化にも関与すると考えられている. また, いくつかの研究に扔いて, 肥満喘息患者 は非肥満喘息患者に比し，ステロイド治療に対 して反応がそしいことが示されている。このこ とは, 肥満関連喘息が好中球性炎症と関連して いることとも関係している，現状では，吸大ス テロイド薬が喘息治療薬の主役であるため, ス テロイド抵抗性は, 直接的に「喘息の治療抵抗 性 $=$ 難治化」という結果に至る.

肥満喘息患者における減量によって喘息症状 が改善することは, 多くの研究報告で示されて いる。実地臨床でも, 体重の急激な増加の後に 喘息コントロールが悪化し, 減量指導の後に顕 著にコントロールが改善することはしばしば経 験する。しかしながら, 我が国では, 肥満が喘 息の増悪因子であることに関して，未だ多くの 医師に広く認識されていないのが現状である. 一般的に，通常の吸入療法を中心とした薬物療 法でコントロール困難な喘息患者に対し, 内服 ステロイドの継続的な投与を行うことは少なく ないが, 特に肥満関連の難治性喘息患者はステ ロイド抵抗性を示すため, 経口ステロイド薬内 服を行っても症状の改善に乏しく, むしろ, そ の副作用による体重増加は, 理論的には病態の 悪化につながりかねない。この患者群に関して は, 安易にステロイド全身投与のみに頼るのは 危険であり, 食事指導と減量指導を同時進行で 行っていく方が，長期的にみれば，より安全性 が高く, 効果的といえる.

\section{2) AERDへの対応}

AERDは, 喘息難治化因子として最も重要なも
のの1つである. AERDの長期管理は, 基本的に 通常の喘息と同様，吸入ステロイド薬が中心と なる，吸大ステロイド薬を中心とする通常の喘 息治療でコントロールが困難な場合は, 全身性 ステロイド薬や分子標的療法を考慮する. 特に 分子標的療法の1つである抗IgE (immunoglobulin E) 抗体製剤であるオマリズマブに関しては, AERDに対して特に効果的であることが示され ている6).

AERDは高率に好酸球性鼻茸を合併し, それに 対する治療を点鼻ステロイド薬等で行うことも 喘息の安定化のために重要である。再燃しやす い重症の好酸球性鼻苜症例では, 耳鼻咽喉科専 門医と連携して内視鏡下副鼻腔手術を考慮する.

\section{3）真菌感作への対応}

アスペルギルスフミガタスは, 気道内に腐 生・増殖し，アレルゲンを放出してアレルギー 性炎症を悪化させる，喘息患者におけるステロ イド治療は潜在的に真菌への易感染性の原因に なっている可能性が近年指摘されており7), 吸 入ステロイド薬が広く普及すればするほど, 新 しくアスペルギルスフミガタスアレルギーを発 症する喘息患者が増加する可能性が懸念されて いる.アスペルギルスフミガタスへのアレル ギーは血液IgE抗体価検査等を施行しなければ わからないため, 難治性喘息患者に対しては, 年に 1 回はアスペルギルスIgE抗体価測定を行う べきであると我々は考えている。アスペルギル スにIgE感作された喘息患者は, ABPAの診断基 準を満たさなくても, 低肺機能を示し, 喘息が 重症であることが示されている8). ABPAに対す る抗真菌薬の投与が有用であることはRCT(randomized controlled trial）で示されているが, 近 年, ABPAの診断基準を満たさない真菌感作重症 喘息に対しても, 抗真菌薬投与で喘息が改善す るとする報告も認める ${ }^{9)}$. 従って, アスペルギ ルスIgE陽性の非ABPA重症喘息に対して抗真菌 薬の投与を考慮することも選択肢の 1 つである 


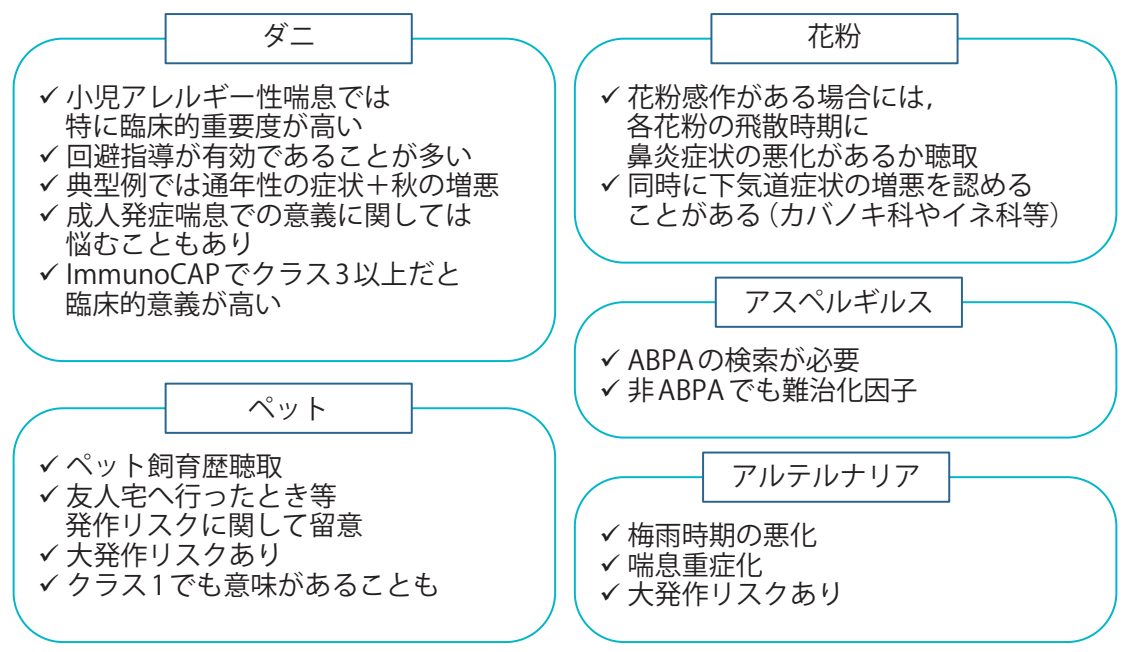

図 2 頻度の高い感作抗原と喘息症状との関係

が，少なくとも，現状では標準治療とは言いが たい. 今後の研究課題と言える.

屋外環境のアルテルナリア胞子の増加と喘息 入院例の増加との関係が以前から指摘されてお り, アルテルナリアへのIgE感作は喘息大発作の 重大な危険因子であると報告されてきた ${ }^{10)}$. 我 が国では，アルテルナリアは，特に梅雨に屋外 飛散量が増加することが明らかになっている。 梅雨に喘息の悪化を訴えるアルテルナリア感作 喘息患者には要注意である ${ }^{10)}$. 服薬アドヒアラ ンスの悪化が重篤な発作につながりやすいた め, 他の患者よりも服薬指導には注力する必要 がある。

\section{4）その他感作アレルゲンへの対応}

概して，アトピー型喘息よりも非アトピー型 喘息の方が重症である傾向にあるが，アトピー 素因が強く関与している難治性喘息患者も存在 する．個々の患者の喘息難治化因子として，あ りふれたアレルゲンへの持続性曝露が関わって いることはしばしば経験する，難治性喘息患者 に対しても, 一度は感作頻度の高い吸入性抗原 に対するIgE抗体価を評価しておく必要がある.
アレルギーの頻度が高いアレルゲン及びそれに よる臨床症状を図2にまとめた。一般に，アト ピー型喘息患者は多種の吸入性抗原にIgE感作 されているが，全ての感作抗原が喘息病態に一 様に関与しているわけではない. 従って, 必ず しも全ての吸入性抗原の回避を一様に行わなけ ればならないわけではないし, 全ての抗原の回 避策を実施することは，患者にとっても困難を 伴うことも多い。しかしながら, 病歴上, 図 2 に示すように, 特定の感作アレルゲンに持続曝 露されており，曝露に伴い，喘息発作が誘発さ れていることが疑われた場合は, 特定のアレル ゲンにフォーカスを絞って回避策を行うこと で，患者にとってもさほどの負担にならない. また，回避による効果を実感できれば，患者自 身も回避策に積極的に取り組むようになる。病 歴を詳細に聴取し，個々の患者にとって病態へ の寄与度が高いアレルゲンを見出すことが臨床 医の役目といえる.

おわりに

難治性喘息の概念，鑑別ならびに対処方法に 
ついて概説した．このような喘息難治化因子に 対する理解は, 我々臨床医にとって, 日常臨床 に直結する極めて重要な情報である。近年, 詳 細な亜型分類に基づいた, 難治性喘息の病態把 握と治療介入に関する研究が進められてきてお り, 将来的に, このような研究の成果が実地臨
床において早期に利用可能となることが期待さ れる。

著者のCOI（conflicts of interest）開示: 本論文発表内容 に関連して特に申告なし

\section{文献}

1）一ノ瀬正和監修：重症喘息一定義，評価，治療に関するERS/ATSガイドライン日本語版一.メディカルレビュー社， 2014.

2）日本アレルギー学会：喘息予防・管理ガイドライン2018. 2018.

3）福冨友馬, 他：国立病院機構気管支喘息調査ネットワーク研究班. 本邦における病院通院成人喘息患者の実態調査： 国立病院機構ネットワーク共同研究。アレルギー 59:37-46, 2010.

4) Haldar P, et al : Cluster analysis and clinical asthma phenotypes. Am J Respir Crit Care Med 178:218-224, 2008.

5) Fukutomi Y, et al : Obesity and aspirin intolerance are risk factors for difficult-to-treat asthma in Japanese nonatopic women. Clin Exp Allergy 42 : 738-746, 2012.

6) Hayashi $\mathrm{H}$, et al : Omalizumab reduces cysteinyl leukotriene and $9 \alpha, 11 \beta$-prostaglandin F2 overproduction in aspirin-exacerbated respiratory disease. J Allergy Clin Immunol 137 : 1585-1587 e4, 2016.

7) Fraczek MG, et al : Corticosteroid treatment is associated with increased filamentous fungal burden in allergic fungal disease. J Allergy Clin Immunol 142: 407-414, 2018.

8) Menzies D, et al : Aspergillus sensitization is associated with airflow limitation and bronchiectasis in severe asthma. Allergy 66 : 679-685, 2011.

9) Denning DW, et al : Randomized controlled trial of oral antifungal treatment for severe asthma with fungal sensitization : The Fungal Asthma Sensitization Trial (FAST) study. Am J Respir Crit Care Med 179 : 11-18, 2009.

10) Fukutomi Y, Taniguchi $M$ : Sensitization to fungal allergens : Resolved and unresolved issues. Allergol Int 64 : 321-331, 2015. 